\title{
Cardioloog en kunstenaar: een giftige combinatie
}

M. Baars

Het is niet altijd gemakkelijk om twee functies te combineren die zo tegengesteld zijn als hartspecialist en kunstenaar. In de ogen van andere mensen overheerst vaak een van beide identiteiten als zij het over mij hebben. Ik vind 'een geloofwaardig kunstenaar zijn' de moeilijkste positie. Bij kunst gaat het om experimenteren en ideeën, om intuïtie en instinct. Kunst heeft magie en alchemie, maar als arts blijf ik toch altijd achterdochtig jegens degene die in de grote zwarte ketel roert. Bij cardiologie gaat het immers om wetenschap en rationeel denken. Tegelijk cardioloog en kunstenaar zijn is dan ook een giftige combinatie. En als in de kunstwereld bovendien één principe overheerst, dan is het waarschijnlijk het principe dat niets belangrijker is dan de kunst zelf. Hoewel de kunstwereld het onconventionele toejuicht, staat juist deze wereld zelf bol van de conventies. Kunstenaars maken werk dat 'op kunst lijkt' en vertonen gedrag dat stereotypen versterkt. Ook binnen de medische wereld zijn er krachtige stereotypen; hartspecialisten zijn daar een voorbeeld van. In smetteloos wit staan zij in dienst van hun patiënten.

\section{Ik heb mijzelf beter leren kennen sinds mijn medische opleiding}

Ik zie in een patiënt die voor zijn leven vecht ook een kunstwerk. In feite is dit voor mij de mooiste visuele ervaring. Toen ik geneeskunde studeerde was ik nog niet zover dat ik dit kon zien. Ik was bang om te falen als jonge dokter en ik vond het vreselijk dat ik daar zo'n punt van maakte.
Ik kwam echt in conflict met mijzelf: ik wilde heel graag 'scoren' tussen de andere dokters maar vond dat tegelijk onzinnig. Ik realiseerde mij dat ik zo strijdlustig was - zo bang om geen 'topper' te worden dat ik de werkelijke waarden die bij het dokter zijn horen uit het oog begon te verliezen. Gelukkig heb ik mij hervonden in de kunst. Schilderen is als naakt in het atelier staan. Een weldadig middel voor visueel genot. En waarom wil ik symbolisch naakt staan? Om zo mijn frustraties te kunnen afschuiven en verklaren. Het lukt niet altijd om een patiënt te helpen. De kritische stem van de kunstenaar uit de verzorgingsstaat: als je niet kritisch bent, dan ben je in mijn ogen niets meer dan een huichelaar, een illustrator, een designer.

\section{Ik wil horen, zien, ruiken, voelen en proeven...}

Kunstenaars en artsen hebben motieven nodig die dieper gaan dan geld verdienen. Het schilderen is spiritueel. Kunstenaars moeten pionieren. Ik ben niet iemand die door geld wordt gemotiveerd. De doeken worden wel verkocht door galeries en kunsthandelaren, maar daarvoor heb ik ze niet primair gemaakt. Ik wil extatisch, orgiastisch, intensief leven. Ik wil kippenvel voelen en dat aan mijn publiek bezorgen. Ik wil dat mijn publiek hoort, ziet, ruikt, voelt en proeft. Mijn kunst is met diepe psychologie verbonden. Beschaving dwingt ons te verdringen; de kunstenaar in mij probeert verdrongen gedeelten te bereiken, weer naar het bewustzijn te brengen. 


\section{...maar ik wil toch vooral communice- ren...}

Ik wil mij anderzijds ook niet conformeren aan het idee dat kunst altijd maar moet verontrusten en schokken. Dat is toch het idee van de avant-garde in de hedendaagse kunst. De afstand tot de mens is daardoor te groot geworden. Veel kunstenaars lijken niet echt bereid of in staat om via hun werk op een toegankelijke manier te communiceren. Schilderen is dan een ontzettend eenzaam pad. Je hoort nergens bij en dat wil ik niet. Ik snap dat niet; je wilt als kunstenaar toch gehoord en enigszins begrepen worden? De wereldvreemde, navelstarende houding van sommige collega kunstenaars doet me sterk aan een sekte denken. Ik pas daarvoor, ik ben verdomme een gevoelsmens.

\section{....maar dan wel met een groot \\ publiek...}

Mijn grote zwakheid is misschien juist wel mijn obsessie voor publieke belangstelling; ik ben hypergevoelig voor een wijder bereik van mijn kunst maar wil dat niet op een commerciële manier. Als kunstenaar besef ik dat het essentieel is om een groot publiek te bereiken. Dat grote publiek is voor mij belangrijk. Als je alleen voor een handvol intellectuelen kunst maakt, kun je beter met hen naar de kroeg gaan en daar gaan debatteren. Ik wil dat mijn kunst ook door mensen buiten de 'inner circle' van de kunstwereld wordt geapprecieerd. Ach, misschien ben ik wel ijdel en exhibitionistisch. Als anderen dat over mij zeggen, interesseert mij dat niet. Het werk dat ik doe als kunstenaar, maar ook als cardioloog, is een ingenieus spel; het is spelen in de meest serieuze zin van het woord, zoals een kind ontdekt hoe het een blokkentoren kan bouwen. De behoefte om mij te uiten heb ik altijd gehad en ik schilder altijd voor de eeuwigheid én voor het moment nu. Waarom zou je je dan als kunstenaar moeten verklaren? Mijn schilderen is zo visueel dat het heel moeilijk is er iets over te zeggen zonder dat te kort te doen. Ik vind het demystificeren van beide identiteiten belangrijk. Een mens moet weten dat je alles kan als je maar wilt. Kunst wordt gemaakt door gewone mensen en kunstenaars én cardiologen zijn mensen die net zo zijn als alle anderen. Als ik naar mijzelf kijk, zie ik een gewone man, maar waarom zou ik niet spitsroeden blijven lopen?

\section{...en daarbij is eigentijdsheid mij vreemd}

Mijn kunst heeft een iconische, mannelijke agressie. Mijn figuren zwelgen in vervorming en kleuren. Lichamelijk en grof. Dat is de taal die ik het meest vertrouw. Ik ben met name geïnspireerd en beïnvloed door de CoBrA schilders van na de Tweede Wereldoorlog en het abstract-expressionalisme van de jaren vijftig en zestig. Terugkijken is voor mij essentieel om het heden te kunnen begrijpen. Eigentijdsheid is een weerspiegeling van het consumentengedrag dat je overal in onze cultuur ziet, van damestasje tot nieuwste model auto. Veel kunstenaars zijn welhaast obsessief met het volgen van de trend bezig. Ik doe daar niet aan mee. Ik leid eigenlijk een schizofreen leven. Ik doe nauwgezet en secuur mijn werk in het ziekenhuis, maar heb daarbij altijd geschilderd en zal dat ook blijven doen. Ik blijf vaak de hele nacht op om te schilderen, met name doe ik dat als ik oproepbaar ben voor de spoedeisende hulp of bijvoorbeeld voor de hartbewaking. Ik schilder dan om de druk van leven en dood - die dan op mijn schouders rust - te negeren. Als ik niet was gaan schilderen was ik krankzinnig geworden. Door het schilderen ben ik gaan beseffen dat ik anders was. Schilderen betekent: nadenken over wie je bent, over wat je 


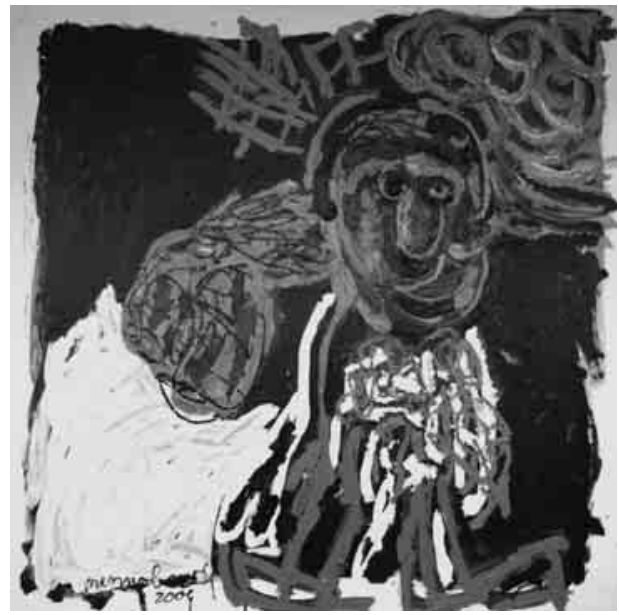

Afbeelding 1. Mexican Woman, $180 \times 180 \mathrm{~cm}$, olieverf op linnendoek, 2009 - Menno Baars.

doet en wat je gaat doen. Het blijft natuurlijk een schizoïde bezigheid, want er is altijd iemand die kijkt wat je doet en hoe je het doet. Ik onderzoek niet de sociale en culturele ideeën van deze tijd. Ik vind dat een kunstwerk genot moet verschaffen en emoties moet oproepen. Net zoals ik deze ervaar wanneer ik een patiënt 'er doorheen sleep'.

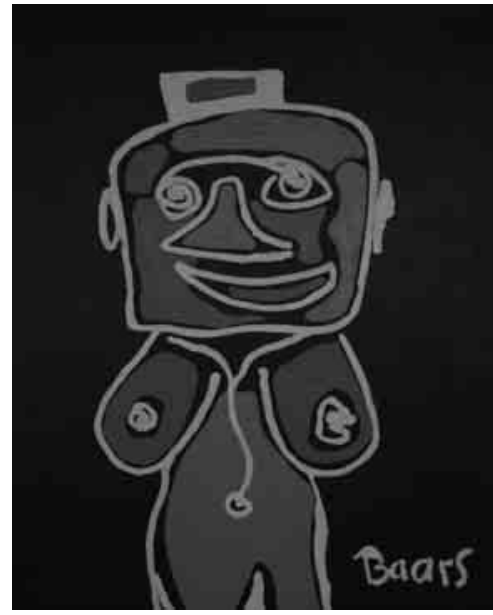

Afbeelding 2. Naughty Nurse, $80 \times 100 \mathrm{~cm}$, acrylverf op linnendoek, 2004 - Menno Baars.

De auteur:

Menno Baars is professioneel beeldend kunstenaar en is daarnaast als cardioloog verbonden aan een ziekenhuis. Na zijn studie geneeskunde is Menno Baars gaan schilderen; hij heeft geen kunstacademie bezocht. Eind 2006 kwam het overzicht "Hart Voor Elkaar" uit (Lannoo, Brussel) samen met Dichter des Vaderlands, Driek van Wissen. In 2007 neemt Menno Baars deel aan verschillende Amerikaanse kunstbeurzen en heeft hij exposities in o.a. Monaco en Dubai. Zijn werk bevindt zich in collecties van o.a. Microsoft en het JFK Airport New York.

Correspondentieadres:

M. Baars, postbus 2067, 8203 AB Lelystad.

Belangenconflict: geen gemeld

Financiële ondersteuning: geen gemeld 